\title{
The Orofacial Pain Clinic Questionnaire (EDOF-HC) in the evaluation and diagnosis of orofacial pain
}

\author{
Questionário da Equipe de Dor Orofacial (EDOF-HC) na avaliação e diagnóstico da dor orofacial \\ Silvia Regina Dowgan Tesseroli de SIQUEIRA',2, Manoel Jacobsen TEIXEIRA², José Tadeu Tesseroli de SIQUEIRA',2
}

\begin{abstract}
Background: Diagnostic tools are necessary for the anamnesis and examination of orofacial pain, in order to fulfill diagnostic criteria and to screen potential causes of pain. Objective: To evaluate the Orofacial Pain Clinic Questionnaire (EDOF-HC) in the assessment and diagnosis of orofacial pain. Methods: Overall, 142 patients were evaluated and classified according to the criteria of the International Headache Society and International Association for the Study of Pain. All of them were evaluated with the EDOF-HC questionnaire, which consists of the orofacial and medical history, as well as the orofacial examination. Data were statistically analyzed with chi-square test and Bonferroni correction, one-way ANOVA with Tukey post hoc test, the two-step cluster and decision tree methods. Results: There were diferences in pain descriptors, pain in maximum mouth opening, number of trigger points, and history of previous surgery between the groups, which were classified into trigeminal neuralgia, burning mouth syndrome, temporomandibular disorders and trigeminal posttraumatic neuropathic pain with classification analysis. Conclusions: The EDOF-HC is a clinical supportive tool for the assessment of orofacial pain. The instrument may be used to support data collection from anamnesis and examination of patients according to the diagnostic criteria of most common orofacial conditions. It is also useful in the investigation of local and systemic abnormalities and contributes for the diagnosis of conditions that depend on exclusion criteria.
\end{abstract}

Keywords: Neuropathic pain; Orofacial Pain; Trigeminal Neuralgia; Temporomandibular Disorders; Diagnosis; Questionnaire.

\section{RESUMO}

Introdução: Instrumentos diagnósticos são necessários para a anamnese e exame da dor orofacial, auxiliando na identificação das causas potenciais de dor. Objetivo: Avaliar o Questionário da Equipe de Dor Orofacial (EDOF-HC) na abordagem e diagnóstico da dor orofacial. Métodos: Ao todo, 142 pacientes foram avaliados e classificados de acordo com os critérios da Sociedade Internacional de Cefaleias e da Associação Internacional para o Estudo da Dor. Todos foram avaliados com o questionário EDOF-HC, que consiste na anamnese orofacial e médica, além do exame físico orofacial. Os dados foram analisados estatisticamente com os testes qui-quadrado com correção de Bonferroni, ANOVA de um fator e post hoc de Tukey, além dos métodos de classificação em cluster e árvore decisória. Resultados: Houve diferenças entre os diagnósticos quanto aos descritores da dor, dor na abertura bucal máxima, número de pontos-gatilho mastigatórios e história prévia de cirurgia, o que esteve de acordo com a classificação nos diagnósticos de neuralgia do trigêmeo, síndrome da ardência bucal, disfunção temporomandibular e dor neuropática pós-traumática trigeminal. Conclusões: O Questionário da Equipe de Dor Orofacial (EDOF-HC) mostrou ser um instrumento de apoio para a avaliação da dor orofacial, útil na coleta de dados de anamnese e exame clínico dos pacientes, observando os principais sinais e sintomas relacionados aos critérios diagnósticos das condições orofaciais dolorosas mais comuns. Também é útil na avaliação de comorbidades locais e sistêmicas e contribui para o diagnóstico de condições que dependem em critérios de exclusão.

Palavras-chave: Neuralgia; Dor Facial; Neuralgia do Trigêmeo; Transtornos da Articulação Temporomandibular; Diagnóstico; Questionário.

The diagnosis of orofacial pain is a challenge due to the complexity of the trigeminal nuclear system, the high frequency of referred pain in the craniofacial region and the high prevalence of pain diagnoses in this area ${ }^{1,2}$.
Although neuropathic pain has specific characteristics that help in the identification of the diagnostic entity (e.g., shock-like and burning descriptors, sensory loss, alodynia) $)^{3,4}$, there are idiopathic conditions based on exclusion

${ }^{1}$ Universidade de São Paulo, Faculdade de Medicina, Departamento de Neurologia, Clínica de Dor Orofacial, São Paulo SP, Brazil.

${ }^{2}$ Universidade de São Paulo, Faculdade de Medicina, Departamento de Neurologia, Grupo Interdisciplinar de Dor, São Paulo SP, Brazil.

Silvia Regina Dowgan Tesseroli de SIQUEIRA (D) https://orcid.org/0000-0003-0207-0072; Manoel Jacobsen TEIXEIRA (D) https://orcid.org/0000-0002-7974-6045; José Tadeu Tesseroli de SIQUEIRA (iD https://orcid.org/0000-0002-9721-1634

Correspondence: Silvia Regina Dowgan Tesseroli de Siqueira; E-mail: silviadowgan@hotmail.com

Conflict of interest: There is no conflict of interest to declare.

Received on August 9, 2019; Received in its final form on November 27, 2019; Accepted on December 5, 2019. 
criteria (neuropathic or controversial), such as persistent idiopathic facial pain (PIFP), atypical odontalgia (AO) and burning mouth syndrome (BMS) $)^{5,6}$, which need a careful investigation that considers other primary potential causes of pain. Besides that, temporomandibular disorder (TMD) is characterized by a dysfunction of the masticatory system, and it may be the primary or secondary diagnosis among orofacial pain conditions?

Over the last decades, the Orofacial Pain Clinic Questionnaire (EDOF-HC) has been used as the main tool to obtain relevant information from patients with orofacial pain in our clinic ${ }^{8}$. It is in accordance with the diagnostic criteria from the International Association for the Study of Pain (IASP) ${ }^{9}$ and the International Headache Society $(\mathrm{IHS})^{10}$. Our group has published several studies on the diagnoses of orofacial conditions and characteristics that used this questionnaire in the methodology $y^{11,12,13,14,15}$, and it has shown to be effective to obtain major information from the patient's anamnesis and examination to gather clinical hypotheses for the diagnosis.

One of the main challenges in patients with orofacial pain is the identification of masticatory musculoskeletal complaints that correspond to primary TMD, myofascial symptoms that might be secondary to other orofacial diagnoses and neuropathic conditions of the craniofacial region ${ }^{11}$. Within this scenario the aim of the present study was to evaluate the EDOF-HC as a tool in the assessment and diagnosis of orofacial pain.

\section{METHODS}

\section{Subjects}

Overall, 142 patients with orofacial pain from the Orofacial Pain Clinic of a general hospital participated in the study. All patients who came for the evaluation of neuropathic orofacial pain between 2002 and 2012 were included in research. In this sample, 121 (85.2\%) were female and the mean ages were $55.9 \pm 15.6$ (confidence interval: $53.3 \leq \mu \leq 58.5$ ) years.

All patients were evaluated by a trained dentist, who is specialized in orofacial pain and temporomandibular disorders. They were diagnosed according to the criteria from the IHS $^{10}$ and the criteria of IASP ${ }^{8}$. Of them, $42(29.6 \%)$ had trigeminal neuralgia, 36 (25.4\%) had BMS, 12 (8.5\%) had PIFP, $12(8.5 \%)$ had trigeminal posttraumatic neuropathic pain (tPTN), 30 (21.1\%) had TMD, and 10 (7.0\%) had AO. These diagnostic criteria aim to identify the patients of each condition, based on their clinical features and presentation, to achieve relatively homogeneous samples for a comparision between the criteria and other diagnostic tools, such as a questionnaire.

\section{Evaluation}

The EDOF-HC ${ }^{14}$ consists of three separate sections: orofacial anamnesis, medical anamnesis, and clinical examination (Appendix 1 - English version; the Brazilian version is available trough contact with the corresponding author of the manuscript).

In this tudy, we included data from the orofacial anamnesis and clinical examination, which consists of: demographic characteristics, pain complaints and duration, pain intensity and descriptors, triggering, worsening and alleviation factors, crises characteristics, periodicity, oral habits, pain when waking-up, previous dental and surgical treatments, quality of chewing, bruxism, quality of sleep, earache, headache and body pain complaints, sensation of tired face, and the evaluation of pain in mandibular movements, articular noises, maximum mouth opening, masticatory and cervical muscular palpation, dental occlusion, evaluation of cervical movements, use of prosthesis, and characteristics of facial skin, oral mucosa, tongue, periodontal tissues and teeth.

\section{Statistical analysis}

All data were distributed in tables, and the descriptive analysis included frequencies, percentages (categorical data) and means, standard deviations and confidence intervals (quantitative data). Missing data were treated as missing and not excluded or substituted by any value. Normal distribution was assumed by the Central Limit Theorem. The following statistical tests were used: chi-square with Bonferroni correction, and one-way ANOVA with Tukey post hoc test. Data were classified after a descriptive analysis with two-steps cluster and outliers treatment, which excluded one case $(0.7 \%)$, and with the decision tree $(90 \%$ training sample).

The level of significance was $5 \%$ and the analysis was performed with the SPSS software 17.0 (IBM).

\section{RESULTS}

Patients with BMS and TN were older than the other patients (mean ages of $62.9 \pm 13.1$ and $61.6 \pm 12.6$ respectively), there were proportionally less women in the groups of TN (30; $71.4 \%$ women) and PIFP (7; 58.3\% women) than in the other groups, and there were less patients working in the groups of BMS $(9 ; 25.0 \%)$ and $\operatorname{tPTN}(3 ; 25.0 \%)$.

According to pain characteristics, the only difference was of pain descriptors (Table 1). TN was associated to shocklike pain, BMS to burning, and TMD to throbbing and multiple descriptors. There were no differences between the groups of pain intensity ( $\mathrm{p}=0.345)$, number of pain descriptors $(\mathrm{p}=0.167)$ and duration of pain $(\mathrm{p}=0.064)$. 
TN, BMS and TMD had specific characteristics of worsening factors and spontaneous/provoked pattern (Table 1). $\mathrm{TN}$ was associated to fewer oral habits and a shorter pattern of duration, and there were diferences between the groups, according to previous treatments (Table 2).

Most patients presented a bad (32; 22.5\%) or regular (43; $30.3 \%)$ quality of chewing, with no diferences between the groups ( $\mathrm{p}=0.133) ; 80$ (56.3\%) patients had pain when wakingup and 66 (46.5\%) had the sensation of tired face. The groups of patients also had similar periodicity (daily in $118 ; 83.1 \%$, $\mathrm{p}=0.113$ ), pain in all mandibular movements $(51 ; 35.9 \%$, $\mathrm{p}>0.050$ ), and bruxism (awake: 6; 4.2\%, $\mathrm{p}=0.831$ and asleep: $38 ; 26.8 \%, \mathrm{p}=0.468$ ).
There were no diferences in the prevalence of earache $(p>0.050)$ and the quality of sleep $(\mathrm{p}=0.166)$. However, patients with TMD had more headaches (26; $86.7 \%, \mathrm{p}=0.005)$, body pain $(24 ; 80 \%, \mathrm{p}=0.005)$, and pain in cervical movements $(22 ; 73.3 \%, \mathrm{p}=0.005)$. Pain at the palpation of the temporomandibular joint was also worse in TMD patients than in the other groups $(24 ; 80 \%, \mathrm{p}<0.001$, the worst in TMD). These patients had more pain at maximum mouth opening and more trigger points, whereas TN patients had the lowest mean of trigger points (Table 3).

There were no diferences in the prevalence of periodontal disease between the groups $(p=0.453)$ or in the use of dentures $(p=0.690)$. The groups were also

Table 1. Pain characteristics and patterns according to the diagnosis.

\begin{tabular}{|c|c|c|c|c|}
\hline & $\begin{array}{l}\text { Spontaneous } \\
\text { or provoked }\end{array}$ & $\begin{array}{l}\text { Main pain } \\
\text { descriptor }\end{array}$ & $\begin{array}{l}\text { Worsening } \\
\text { factors }\end{array}$ & $\begin{array}{l}\text { Alleviation } \\
\text { factors }\end{array}$ \\
\hline TN (42; 29.6\%) & $\begin{array}{c}27(54.3 \%) \text { spontaneous } \\
14(33.3 \%) \text { provoked* } \\
1(8.3 \%) \text { missing }\end{array}$ & $\begin{array}{c}33(78.6 \%) \text { shock-like** } \\
8(19.0 \%) \text { multiple } \\
1(2.4 \%) \text { numbness }\end{array}$ & $\begin{array}{c}13(31.0 \%) \text { cold** } \\
1(2.4 \%) \text { warm } \\
12(28.6 \%) \text { emotional } \\
\text { distress } \\
2(4.8 \%) \text { acid or spicy food } \\
13(31.0 \%) \text { chewing } \\
9(21.4 \%) \text { talking** } \\
6(14.3 \%) \text { mandibular } \\
\text { movements } \\
3(7.1 \%) \text { touch }\end{array}$ & $\begin{array}{c}18(42.9 \%) \text { medication } \\
1(2.4 \%) \text { physiotherapy } \\
4(9.5 \%) \text { rest } \\
4 \text { (9.5\%) emotional coping } \\
1(2.4 \%) \text { warm }\end{array}$ \\
\hline BMS (36; 25.4\%) & $\begin{array}{c}35(97.2 \%) \\
\text { spontaneous**} \\
1(2.8 \%) \text { missing }\end{array}$ & $\begin{array}{c}1(2.8 \%) \text { shock-like } \\
25(69.4 \%) \text { burning** } \\
9(25.0 \%) \text { multiple } \\
1(2.8 \%) \text { missing }\end{array}$ & $\begin{array}{c}2(5.6 \%) \text { cold } \\
2(5.6 \%) \text { warm } \\
7(19.4 \%) \text { emotional distress } \\
4(11.1 \%) \text { acid or spicy food } \\
4(11.1 \%) \text { chewing } \\
1(2.8 \%) \text { touch }\end{array}$ & $\begin{array}{c}11(30.6 \%) \text { medication } \\
2(5.6 \%) \text { physiotherapy } \\
1(2.8 \%) \text { rest } \\
2(5.6 \%) \text { cold } \\
4(11.1 \%) \text { food }\end{array}$ \\
\hline TMD (30; 21.1\%) & $\begin{array}{c}20(66.7 \%) \text { spontaneous } \\
8(26.7 \%) \text { provoked } \\
2(6.7 \%) \text { missing }\end{array}$ & $\begin{array}{c}2(6.7 \%) \text { shock-like } \\
1(3.3 \%) \text { burning } \\
17(56.0 \%) \text { multiple } \\
7(23.3 \%) \text { throbbing } \\
2(6.7 \%) \text { pressing } \\
1(3.3 \%) \text { missing }\end{array}$ & $\begin{array}{c}4(13.0 \%) \text { cold } \\
1(3.3 \%) \text { warm } \\
6(20.0 \%) \text { emotional distress } \\
5(16.7 \%) \text { chewing } \\
3(10.0 \%) \text { talking } \\
5(16.7 \%) \text { mandibular } \\
\text { movements } \\
6(20.0 \%) \text { exercises } *\end{array}$ & $\begin{array}{c}14(46.7 \%) \text { medication } \\
5(16.7 \%) \text { physiotherapy } \\
7(23.3 \%) \text { rest } \\
3(10.0 \%) \text { emotional coping } \\
2(6.7 \%) \text { warm }\end{array}$ \\
\hline tPTN (12; 8.5\%) & $\begin{array}{c}9(75.0 \%) \text { spontaneous } \\
2(16.7 \%) \text { provoked } \\
1(8.3 \%) \text { missing }\end{array}$ & $\begin{array}{c}5(41.7 \%) \text { shock-like } \\
5(41.7 \%) \text { multiple } \\
1(8.3 \%) \text { numbness } \\
1(8.3 \%) \text { missing }\end{array}$ & $\begin{array}{c}3(25.0 \%) \text { cold } \\
1(8.3 \%) \text { warm } \\
3(25.0 \%) \text { emotional distress } \\
3(25.0 \%) \text { chewing } \\
2(16.7 \%) \text { talking } \\
1(83.0 \%) \text { mandibular } \\
\text { movements }\end{array}$ & $\begin{array}{c}3(25.0 \%) \text { medication } \\
1(8.3 \%) \text { physiotherapy } \\
3(25.0 \%) \text { rest } \\
2(16.7 \%) \text { warm }\end{array}$ \\
\hline PIFP (12; 8.5\%) & $\begin{array}{c}10(83.3 \%) \text { spontaneous } \\
2(16.7 \%) \text { provoked }\end{array}$ & $\begin{array}{l}1(8.3 \%) \text { burning } \\
7(58.3 \%) \text { multiple } \\
3(25.1 \%) \text { throbbing } \\
1(8.3 \%) \text { missing }\end{array}$ & $\begin{array}{c}5(41.7 \%) \text { cold } \\
5(41.7 \%) \text { emotional distress } \\
2(16.7 \%) \text { chewing } \\
1(8.3 \%) \text { teeth brushing }\end{array}$ & $\begin{array}{c}7(58.3 \%) \text { medication } \\
2(16.7 \%) \text { rest }\end{array}$ \\
\hline $\mathrm{AO}(10 ; 7.0 \%)$ & $\begin{array}{l}9(90.0 \%) \text { spontaneous } \\
1(10.0 \%) \text { provoked }\end{array}$ & $\begin{array}{l}8(80.0 \%) \text { burning } \\
1(10.0 \%) \text { multiple } \\
1(10.0 \%) \text { throbbing }\end{array}$ & $\begin{array}{c}2(20.0 \%) \text { cold } \\
1(10.0 \%) \text { warm } \\
1(10.0 \%) \text { chewing } \\
2(20.0 \%) \text { mandibular } \\
\text { movements } \\
1(10.0 \%) \text { teeth brushing }\end{array}$ & $\begin{array}{c}1(10.0 \%) \text { medication } \\
2(20.0 \%) \text { physiotherapy } \\
1(10.0 \%) \text { rest } \\
1(10.0 \%) \text { food }\end{array}$ \\
\hline$p$-value* & 0.011 & $<0.001$ & 0.032 & $>0.050$ \\
\hline
\end{tabular}

TN: trigeminal neuralgia; BMS: burning mouth syndrome; TMD: temporomandibular disorder; tPNH: trigeminal postherpetic neuralgia; PIFP: persistent idiopathic facial pain; AO: atypical odontalgia. ${ }^{\star}$ Chi-square test; $* *$ significance after Bonferroni correction. 
similar about dental occlusion. In the complete sample, 7 (4.9\%) had open mouth, 16 (11.3\%) overbite, 4 (2.8\%) crossbite, 3 (2.1\%) overjet, and 27 (19.0\%) had loss of vertical dimension. Patients with TN had fewer remaining teeth $(11.7 \pm 11.2 \mathrm{p}=0.007)$ and patients with BMS had more abnormalities at the tongue than the other patients (Table 4).

Cluster classification distributed the patients according to this previous descriptive analysis into three groups (TN, BMS, TMD) and one of outliers (tPTN). $\mathrm{OA}$ and PIFP had variable patterns and were not mostly included in only one cluster (Table 5). In the decision tree analysis, the number of trigger points was the first and only fator of classification, significant to distinguish TN from TMD (Figure 1).

\section{DISCUSSION}

This study shows that the EDOF-HC was able to distinguish between TN, BMS, TMD and TPTN, according to the pain descriptors, pain in mouth opening and number of trigger points, and previous history of surgery. Although PIFP and OA did not present typical characteristics, these conditions are based on exclusion ${ }^{10}$ and, in that aspect, this instrument showed to be complete due to the wide anamnesis and examination to determine potential primary causes of pain in these patients. In a certain way, the study shows that the clinical features of patients, assessed with the questionnaire, correspond to the diagnostic criteria of those conditions, making the questionnaire reliable for the clinical activity during the diagnosis of orofacial pain diseases.

Table 2. Previous dental treatments, surgeries, oral habits and crises according to the diagnosis.

\begin{tabular}{|c|c|c|c|c|}
\hline & $\begin{array}{c}\text { Previous } \\
\text { dental treatments }\end{array}$ & $\begin{array}{c}\text { Number of } \\
\text { previous surgeries }\end{array}$ & $\begin{array}{l}\text { Crises } \\
\text { duration }\end{array}$ & $\begin{array}{c}\text { Oral } \\
\text { habits }\end{array}$ \\
\hline TN (42; 29.6\%) & $\begin{array}{c}20(47.6 \%) \text { medication } \\
3(7.1 \%) \text { physiotherapy } \\
14(33.3 \%) \text { dental } \\
6(14.3 \%) \text { neurosurgery } \\
3(7.1 \%) \text { laser } \\
7(16.7 \%) \text { acupuncture } \\
1(2.4 \%) \text { homotherapy } \\
1(2.4 \%) \text { splint } \\
2(4.8 \%) \text { warm compression }\end{array}$ & $0.24 \pm 0.62$ & $\begin{array}{c}14(33.3 \%) \text { seconds**} \\
7(16.7 \%) \text { minutes } \\
7(16.7 \%) \text { hours } \\
12(28.6 \%) \text { days } \\
2(4.8 \%) \text { missing }\end{array}$ & $6(14.3 \%) * *$ \\
\hline BMS (36; 25.4\%) & $\begin{array}{c}13(36.1 \%) \text { medication } \\
4(11.1 \%) \text { topic medication** } \\
5(13.9 \%) \text { physiotherapy } \\
3(8.3 \%) \text { surgery } \\
1(2.8 \%) \text { laser } \\
1(2.8 \%) \text { acupuncture }\end{array}$ & $0.11 \pm 0.40$ & $\begin{array}{l}3(8.3 \%) \text { minutes } \\
11(30.6 \%) \text { hours } \\
21(58.3 \%) \text { days } \\
1(2.8 \%) \text { missing }\end{array}$ & $15(41.7 \%)$ \\
\hline TMD (30; 21.1\%) & $\begin{array}{c}12(40.0 \%) \text { medication } \\
9(30.0 \%) \text { physiotherapy } \\
1(3.3 \%) \text { dental } \\
2(6.7 \%) \text { surgery } \\
8(26.7 \%) \text { acupuncture } \\
3(10.0 \%) \text { splint } \\
1(3.3 \%) \text { warm compression }\end{array}$ & $0.03 \pm 0.18$ & $\begin{array}{l}2(6.7 \%) \text { seconds } \\
4(13.3 \%) \text { minutes } \\
7(23.3 \%) \text { hours } \\
15(50.0 \%) \text { days } \\
2(6.7 \%) \text { missing }\end{array}$ & $11(36.7 \%)$ \\
\hline tPTN $(12 ; 8.5 \%)$ & $\begin{array}{c}5(41.7 \%) \text { medication } \\
1(8.3 \%) \text { physiotherapy } \\
1(8.3 \%) \text { dental } \\
6(50 \%) \text { surgery** } \\
1(8.3 \%) \text { acupuncture }\end{array}$ & $0.58 \pm 0.51 * * *$ & $\begin{array}{c}2(16.7 \%) \text { minutes } \\
6(50.0 \%) \text { hours } \\
3(25.0 \%) \text { days } \\
1(8.3 \%) \text { missing }\end{array}$ & $6(50.0 \%)$ \\
\hline PIFP (12; 8.5\%) & $\begin{array}{c}8(66.7 \%) \text { medication } 2(16.7 \%) \\
\text { physiotherapy } \\
4(33.3 \%) \text { dental } \\
3(25.0 \%) \text { surgery } \\
5(41.7 \%) \text { acupuncture**} \\
1(8.3 \%) \text { splint }\end{array}$ & $0.25 \pm 0.45$ & $\begin{array}{c}1(8.3 \%) \text { minutes } \\
6(50.0 \%) \text { hours } \\
4(33.3 \%) \text { days } \\
1(8.3 \%) \text { missing }\end{array}$ & $6(50.0 \%)$ \\
\hline $\mathrm{AO}(10 ; 7.0 \%)$ & $\begin{array}{c}4(40.0 \%) \text { medication } \\
2(20.0 \%) \text { physiotherapy } \\
4(40.0 \%) \text { dental } \\
1(10.0 \%) \text { surgery } \\
1(10.0 \%) \text { acupuncture } \\
1(10.0 \%) \text { splint }\end{array}$ & $0.30 \pm 0.48$ & $\begin{array}{c}1(10.0 \%) \text { minutes } \\
2(20.0 \%) \text { hours } \\
7(70.0 \%) \text { days }\end{array}$ & $5(50.0 \%)$ \\
\hline$p$-value* & $<0.017$ & 0.009 & $<0.001$ & 0.034 \\
\hline
\end{tabular}

TN: trigeminal neuralgia; BMS: burning mouth syndrome; TMD: temporomandibular disorder; tPNH: trigeminal postherpetic neuralgia; PIFP: persistent idiopathic facial pain; AO: atypical odontalgia. ${ }^{\star}$ Chi-square and oneway ANOVA; ** significance after Bonferroni correction; *** significance Tukey post hoc test. 
From these results, it becomes evident that pain descriptors are a potential clue for the etiology of pain, as supported by literature ${ }^{16}$, but trigger points and pain in maximum mouth opening were important in the evaluation and determination of TMD. Other associated factors were the shock-like descriptor in $\mathrm{TN}$, and burning in BMS (located at the tongue and with a high frequency of tongue abnormalities), which corresponds to the scientific literature ${ }^{4,6}$. tPTN was associated to the surgical procedures that are common etiological factors of this condition $^{3,10}$. Moreover, TN was associated to provoked pain (pain triggering) and a short duration (seconds) ${ }^{4}$, whereas BMS had spontaneous beginning of the crises.
This instrument makes a complete evaluation of the orofacial region, including the examination of all oral tissues and the masticatory system, which turns it into a good tool for the screening of potential primary causes of pain, mostly relevant for PIFP, BMS and AO (due to the diagnostic criteria of this conditions, dependent on exclusion) $)^{5,6}$. However, it is also important for other pains, such as TN (that might have secondary causes of pain from the teeth due to lack of oral hygiene - and myofascial pain - due to facial contractions during the crises and sensitization of the masticatory muscular system from pain chronification $)^{11}$. These secondary causes of pain may play a role in

Table 3. Jaw evaluation according to the diagnosis.

\begin{tabular}{|c|c|c|c|c|}
\hline & $\begin{array}{l}\text { Articular } \\
\text { noises }\end{array}$ & $\begin{array}{l}\text { Number of } \\
\text { trigger points }\end{array}$ & $\begin{array}{l}\text { Max mouth } \\
\text { opening }(\mathrm{mm})\end{array}$ & $\begin{array}{l}\text { Pain at maximum } \\
\text { mouth opening }\end{array}$ \\
\hline TN $(42 ; 29.6 \%)$ & $\begin{array}{l}2(4.8 \%) \text { crepitus } \\
12(28.6 \%) \text { click }\end{array}$ & $1.4 \pm 2.0 * * *$ & $45.6 \pm 8.2$ & $9(21.4 \%)$ \\
\hline BMS (36; 25.4\%) & $\begin{array}{c}6(16.7 \%) \text { crepitus } \\
9(25 \%) \text { click }\end{array}$ & $1.9 \pm 2.4$ & $45.0 \pm 8.4$ & $9(25.0 \%)$ \\
\hline TMD (30; 21.1\%) & $\begin{array}{l}4(13.3 \%) \text { crepitus } \\
8(26.7 \%) \text { click }\end{array}$ & $4.1 \pm 1.8 * * *$ & $44.4 \pm 8.6$ & $21(70.0 \%) * *$ \\
\hline tPTN (12; 8.5\%) & $\begin{array}{l}2(16.7 \%) \text { crepitus } \\
3(25 \%) \text { click }\end{array}$ & $4.2 \pm 2.5$ & $43.6 \pm 8.0$ & $8(66.7 \%)$ \\
\hline PIFP (12; 8.5\%) & $\begin{array}{l}1(8.3 \%) \text { crepitus } \\
2(16.7 \%) \text { click }\end{array}$ & $2.5 \pm 2.5$ & $42.3 \pm 6.3$ & $5(41.7 \%)$ \\
\hline $\mathrm{AO}(10 ; 7 \%)$ & $3(30 \%)$ click & $1.7 \pm 1.6$ & $46.0 \pm 8.1$ & $0(0 \%)$ \\
\hline p-value* & 0.848 & $<0.001$ & 0.825 & $<0.001$ \\
\hline
\end{tabular}

TN:trigeminal neuralgia; BMS: burning mouth syndrome;TMD:temporomandibular disorder; tPNH:trigeminal postherpetic neuralgia; PIFP: persistent idiopathic facial pain; AO: atypical odontalgia. ${ }^{*}$ Chi-square and oneway ANOVA; ${ }^{* *}$ significance after Bonferroni correction; ${ }^{* * *}$ significance after Tukey post hoc test.

Table 4. Orofacial examination according to the diagnosis.

\begin{tabular}{|c|c|c|c|c|}
\hline & Facial skin & Oral mucosa & Tongue & Teeth \\
\hline TN (42; 29.6\%) & $\begin{array}{l}1(2.4 \%) \text { erithema } \\
1(2.4 \%) \text { spots } \\
2(4.8 \%) \text { ulcers }\end{array}$ & $\begin{array}{c}1(2.4 \%) \text { candiasis } \\
2(4.8 \%) \text { gingival } \\
\text { hyperplasia } \\
1(2.4 \%) \text { ulcer } \\
1(2.4 \%) \text { petechiae }\end{array}$ & $\begin{array}{c}11(26.2 \%) \text { fissured } \\
14(33.3 \%) \text { saburrous } \\
2(4.8 \%) \text { dry }\end{array}$ & $\begin{array}{c}3(16.7 \%) \text { decays } \\
7(16.7 \%) \text { teeth } \\
\text { wear of bruxism } \\
1(2.4 \%) \text { implants } \\
1(2.4 \%) \text { sensitivity }\end{array}$ \\
\hline BMS (36; 25.4\%) & $\begin{array}{c}1(2.8 \%) \text { linfonodes } \\
2(5.6 \%) \text { spots } \\
2(5.6 \%) \text { ulcers }\end{array}$ & $\begin{array}{c}2(5.6 \%) \text { mucositis } \\
2(5.6 \%) \text { ulcer } \\
2(5.6 \%) \text { linea alba }\end{array}$ & $\begin{array}{c}15(41.7 \%) \text { fissured**} \\
10(27.8 \%) \text { saburrous**} \\
2(5.6 \%) \text { dry } \\
2(5.6 \%) \text { erithematous }\end{array}$ & $\begin{array}{c}4(11.1 \%) \text { decays } \\
5(13.9 \%) \text { teeth } \\
\text { wear by bruxism } \\
1(2.8 \%) \text { residual roots }\end{array}$ \\
\hline $\operatorname{TMD}(30 ; 21.1 \%)$ & $\begin{array}{c}1(3.3 \%) \text { assimetry } \\
3(10.0 \%) \text { linfonodes }\end{array}$ & $\begin{array}{c}1(3.3 \%) \text { mucositis } \\
1(3.3 \%) \text { ulcer } \\
2(6.7 \%) \text { iquen planus } \\
1(3.3 \%) \text { linea alba }\end{array}$ & $\begin{array}{c}5(16.7 \%) \text { fissured } \\
1(3.3 \%) \text { saburrous } \\
2(6.7 \%) \text { dry }\end{array}$ & $\begin{array}{l}1(3.3 \%) \text { decays } \\
4(13.3 \%) \text { teeth } \\
\text { wear by bruxism }\end{array}$ \\
\hline tPTN (12; 8.5\%) & $\begin{array}{l}2(16.7 \%) \text { assimetry } \\
1(8.3 \%) \text { linfonodes } \\
2(16.7 \%) \text { erithema }\end{array}$ & $1(8.3 \%)$ candidiasis & $\begin{array}{c}2(16.7 \%) \text { fissured } \\
1(8.3 \%) \text { saburrous } \\
1(8.3 \%) \text { erithematous }\end{array}$ & $\begin{array}{c}1(8.3 \%) \text { teeth } \\
\text { wear by bruxism } \\
1(8.3 \%) \text { fracture }\end{array}$ \\
\hline PIFP (12; 8.5\%) & $\begin{array}{c}2(16.7 \%) \text { linfonodes } \\
1(8.3 \%) \text { spots }\end{array}$ & 1 (8.3\%) ulcer & $\begin{array}{c}3(25.0 \%) \text { fissured } \\
2(16.7 \%) \text { saburrous }\end{array}$ & $\begin{array}{l}4(33.3 \%) \text { teeth } \\
\text { wear by bruxism }\end{array}$ \\
\hline $\mathrm{AO}(10 ; 7 \%)$ & $1(10.0 \%)$ assimetry & 1 (10.0\%) linea alba & $\begin{array}{c}2(20.0 \%) \text { fissured } \\
4(40.0 \%) \text { saburrous }\end{array}$ & $\begin{array}{l}1(10.0 \%) \text { teeth } \\
\text { wear by bruxism }\end{array}$ \\
\hline$p$-value* & 0.144 & 0.933 & 0.016 & 0.636 \\
\hline
\end{tabular}

TN: trigeminal neuralgia; BMS: burning mouth syndrome; TMD: temporomandibular disorder; tPNH: trigeminal postherpetic neuralgia; PIFP: persistent idiopathic facial pain; AO: atypical odontalgia. ${ }^{*}$ Chi-square; ${ }^{\star *}$ significance after Bonferroni correction. 
the whole complaint of the patient and need to be assessed and treated as well as the primary causes ${ }^{17}$.

Emotional distress and temperature variations, as well as the general impairment of mandibular functions, were present in all groups of patients, with no statistical differences. These are commonly observed in pain patients in general ${ }^{18}$. However, the examination of mandibular movements (pain in maximum mouth opening and number of trigger points), as well as the complaint of pain in other parts of the body (including the head and neck) were more associated to TMD, indicating that these variables are more indicative of TMD than the impairment of mandibular function and chewing, which occurred in all groups. TMD is recognized as commonly associated to spread pain and other myofascial disorders ${ }^{19}$, as well as having a high prevalence of comorbidities ${ }^{20,21}$, and the EDOF-HC questionnaire was able to screen and evaluate these characteristics in patients.

One limitation of the study is the wide range of characteristics of some of the orofacial conditions that were included. However, these are important entities in the differential diagnosis and the highest challenges in the clinical assessment. The EDOF-HC evaluated a broad spectrum of symptoms and signs with a detailed anamnesis and a complete examination of orofacial tissues that may be involved in primary and secondary causes of orofacial pain.

In conclusion, the EDOF-HC seems to be a supportive tool for the assessment of orofacial pain and can be used to support data collection from anamnesis and patient examination. Moreover, the EDOF-HC is aligned with the diagnostic criteria of most common orofacial conditions and allows investigation of local and systemic abnormalities, thus assisting in the exclusion of primary causes of facial pain and the determination of underlying diagnoses.

\section{ACKNOWLEDGEMENTS}

The authors would like to thank all the orofacial pain/ TMD residents and postgraduate students from the last 20 years who have used the EDOF questionnaire in their research projects.

Table 5. Cluster Classification in two-steps.

\begin{tabular}{|c|c|c|c|c|c|c|}
\hline & & $\begin{array}{c}\text { Cluster } 1 \\
(40 ; 28.4 \%)\end{array}$ & $\begin{array}{l}\text { Cluster } 2 \\
(39 ; 27.6 \%)\end{array}$ & $\begin{array}{c}\text { Cluster } 3 \\
(43 ; 30.5 \%)\end{array}$ & $\begin{array}{c}\text { Outlier Cluster } \\
(19 ; 13.5 \%)\end{array}$ & $p$-value* \\
\hline \multirow{6}{*}{ Diagnoses } & $\mathrm{TN}$ & $36 * *$ & 2 & 0 & 4 & \multirow{6}{*}{$<0.001$} \\
\hline & BMS & 1 & 0 & $34^{\star \star}$ & 1 & \\
\hline & TMD & 1 & $27 * *$ & 1 & 1 & \\
\hline & tPTN & 2 & 2 & 0 & $7 * *$ & \\
\hline & PIFP & 0 & 8 & 0 & 4 & \\
\hline & $\mathrm{OA}$ & 0 & 0 & 8 & 2 & \\
\hline \multirow{7}{*}{ Pain descriptors } & Shock-like & $37 * \star$ & 1 & 0 & 3 & \multirow{7}{*}{$<0.001$} \\
\hline & Burning & 0 & 0 & $33 * \star$ & 2 & \\
\hline & Throbbing & 0 & $9 * *$ & 0 & 2 & \\
\hline & Multiple & 3 & $27 * \star$ & 9 & 8 & \\
\hline & Numbness & 0 & 0 & 0 & $2^{\star}$ & \\
\hline & Pressing & 0 & 2 & 0 & 0 & \\
\hline & Missing & 0 & 0 & 1 & 2 & \\
\hline \multirow{2}{*}{ Previous surgery } & Yes & 3 & 4 & 2 & 12 & \multirow{2}{*}{$<0.001$} \\
\hline & No & 37 & 35 & 41 & $7 * *$ & \\
\hline \multirow{2}{*}{ Pain maximum MO } & Yes & 5 & $30 * *$ & 9 & 7 & \multirow{2}{*}{$<0.001$} \\
\hline & No & 35 & 9 & 34 & 12 & \\
\hline \multirow{2}{*}{$\begin{array}{l}\text { Abnormalities } \\
\text { at the tongue }\end{array}$} & Yes & 16 & 11 & $31 * *$ & 11 & \multirow{2}{*}{$<0.001$} \\
\hline & No & 24 & 28 & 12 & 8 & \\
\hline \multicolumn{2}{|c|}{ Mean number of trigger points } & $\begin{array}{c}1.40 \pm 1.851 \\
(0.81 \leq \mu \leq 1.99)\end{array}$ & $\begin{array}{l}4.21 \pm 2.041 * \star \star \\
(3.54 \leq \mu \leq 4.87)\end{array}$ & $\begin{array}{c}1.93 \pm 2.282 \\
(1.23 \leq \mu \leq 2.63)\end{array}$ & $\begin{array}{c}3.26 \pm 2.491 \\
(2.06 \leq \mu \leq 4.46)\end{array}$ & $<0.001$ \\
\hline
\end{tabular}

TN:trigeminal neuralgia;BMS: burning mouth syndrome;TMD: temporomandibular disorder; tPNH: trigeminal postherpetic neuralgia; PIFP: persistent idiopathic facial pain;AO: atypical odontalgia; MO: mouth opening. ${ }^{*}$ Chi-square and oneway ANOVA; $* \star$ significance after Bonferroni correction; ${ }^{* \star \star}$ significance with Tukey post hoc test. 
Diagnostic

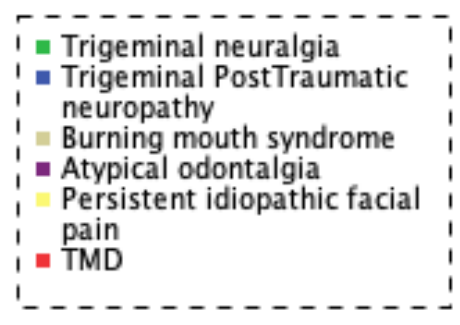

\begin{tabular}{|lrr|}
\hline \multicolumn{1}{|c|}{ Node 0} \\
Category & \multicolumn{1}{c|}{$\%$} & $\mathrm{n}$ \\
\hline Trigeminal neuralgia & 29,1 & 37 \\
Trigeminal Post Traumatic & 7,9 & 10 \\
neuropathy & 26,8 & 34 \\
Burning mouth syndrome & 7,1 & 9 \\
Atypical odontalgia & 8,7 & 11 \\
Persistent idiopathic facial & & \\
pain & 20,5 & 26 \\
TMD & 100,0 & 127 \\
\hline Total & &
\end{tabular}

Number of trigger point in masticatory muscular palpation

Adj. $P$-value $=0,000$, Chi-square $=36,245, d f=5$

\begin{tabular}{|c|c|c|c|c|c|}
\hline \multicolumn{3}{|l|}{ Node 1} & \multicolumn{3}{|l|}{ Node 2} \\
\hline Category & $\%$ & $\mathrm{n}$ & Category & $\%$ & n \\
\hline Trigeminal neuralgia & 46,3 & 25 & Trigeminal neuralgia & 16,4 & 12 \\
\hline $\begin{array}{l}\text { Trigeminal PostTraumatic } \\
\text { neuropathy }\end{array}$ & 1,9 & 1 & $\begin{array}{l}\text { Trigeminal PostTraumatic } \\
\text { neuropathy }\end{array}$ & 12,3 & 9 \\
\hline Burning mouth syndrome & 38,9 & 21 & Burning mouth syndrome & 17,8 & 13 \\
\hline - Atypical odontalgia & 5,6 & 3 & - Atypical odontalgia & 8,2 & 6 \\
\hline $\begin{array}{l}\text { Persistent idiopathic facial } \\
\text { pain }\end{array}$ & 5,6 & 3 & $\begin{array}{l}\text { Persistent idiopathic facial } \\
\text { pain }\end{array}$ & 11,0 & 8 \\
\hline TMD & 1,9 & 1 & TMD & 34,2 & 25 \\
\hline Total & 42,5 & 54 & Total & 57,5 & 73 \\
\hline
\end{tabular}

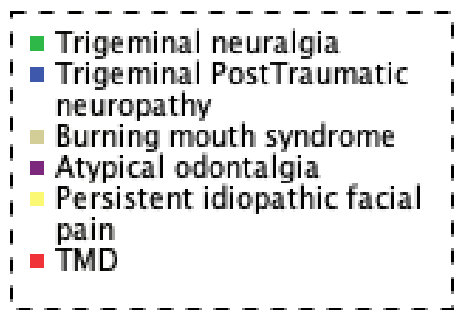

Diagnostic

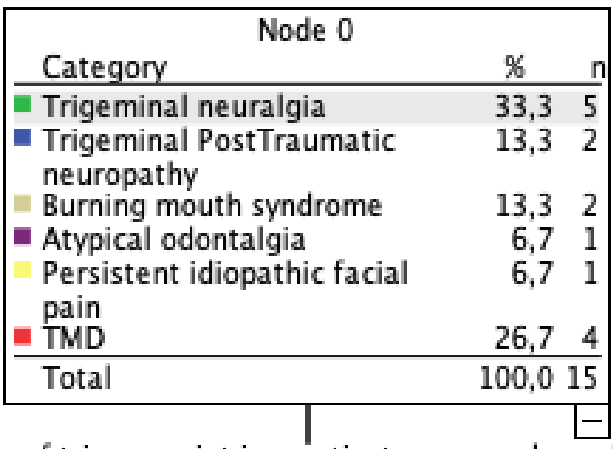

Number of trigger point in masticatory muscular palpation

Adj. $P$-value $=0,000$, Chi-square $=36,245, d f=5$

\begin{tabular}{|c|c|c|c|c|}
\hline \multicolumn{2}{|l|}{ Node 1} & \multicolumn{3}{|l|}{ Node 2} \\
\hline Category & $\%$ & Category & $\%$ & $\mathrm{n}$ \\
\hline Trigeminal neuralgia & 42,93 & Trigeminal neuralgia & 25,0 & 2 \\
\hline $\begin{array}{l}\text { Trigeminal Post Traumatic } \\
\text { neuropathy }\end{array}$ & 14,31 & $\begin{array}{l}\text { Trigeminal Post Traumatic } \\
\text { neuropathy }\end{array}$ & 12,5 & 1 \\
\hline Burning mouth syndrome & 14,31 & Burning mouth syndrome & 12,5 & 1 \\
\hline Atypical odontalgia & 14,31 & - Atypical odontalgia & 0,0 & 0 \\
\hline $\begin{array}{l}\text { Persistent idiopathic facial } \\
\text { pain }\end{array}$ & $0,0 \quad 0$ & $\begin{array}{l}\text { Persistent idiopathic facial } \\
\text { pain }\end{array}$ & 12,5 & 1 \\
\hline TMD & $14,3 \quad 1$ & TMD & 37,5 & 3 \\
\hline Total & $46,7 \quad 7$ & Total & 53,3 & $\overline{8}$ \\
\hline
\end{tabular}

Figure 1. Decision tree. (A) Training sample (90\%); (B) test sample (10\%). 
1. Renton T. Chronic orofacial pain. Oral Dis. 2017 Jul;23(5):566-71. https://doi.org/10.1111/odi.12540

2. Scrivani SJ, Spierings EL. Classification and differential diagnosis of oral and maxillofacial pain. Oral Maxillofac Surg Clin North Am. 2016 Aug;28(3):233-46. https://doi.org/10.1016/j.coms.2016.04.003

3. Baad-Hansen L, Benoliel R. Neuropathic orofacial pain: Facts and fiction. Cephalalgia. 2017 Jun;37(7):670-9. https://doi. org/10.1177/0333102417706310

4. Maarbjerg S, Di Stefano G, Bendtsen L, Cruccu G. Trigeminal neuralgia - diagnosis and treatment. Cephalalgia. 2017 Jun;37(7):648-57. https://doi.org/10.1177/0333102416687280

5. Benoliel R, Gaul C. Persistent idiopathic facial pain. Cephalalgia. 2017 Jun;37(7):680-91. https://doi.org/10.1177/0333102417706349

6. Tu TTH, Takenoshita M, Matsuoka H, Watanabe T, Suga T, Aota Y, et al. Current management strategies for the pain of elderly patients with burning mouth syndrome: a critical review. Biopsychosoc Med. 2019 Jan;13:1. https://doi.org/10.1186/s13030-019-0142-7

7. Graff-Radford SB, Abbott JJ. Temporomandibular Disorders and Headache. Oral Maxillofac Surg Clin North Am. 2016 Aug;28(3):33549. https://doi.org/10.1016/j.coms.2016.03.004

8. Nasri C, Teixeira MJ, Siqueira JTT. Clinical Study of the General Characteristics of Patients with Burning Mouth Complaints.JBA. 2002;2(8):278-84.

9. Merskey H, Bogduk N. Classification of chronic pain. Seattle: IASP; 1994.

10. Headache Classification Committee of the International Headache Society (IHS). The International Classification of Headache Disorders, 3rd edition (beta version). Cephalalgia. 2013;33(9):629-808. https:// doi.org/10.1177/0333102413485658

11. Ichida MC, de Almeida AN, da NóbregaJC, Teixeira MJ, de Siqueira JT, de Siqueira SR. Sensory abnormalities and masticatory function after microvascular decompression or balloon compression for trigeminal neuralgia compared with carbamazepine and healthy controls.J Neurosurg. 2015 Jun;122(6):1315-23. https://doi.org/10.3171/2014.9.JNS14346

12. Nóbrega JC, Siqueira SR, Siqueira JT, Teixeira MJ. Diferential diagnosis in atypical facial pain: a clinical study. Arq Neuropsiquiatr. 2007 Jun;65(2A):256-61. https://doi.org/10.1590/s0004-282×2007000200013
13. Da Silva LA, Kazyiama HH, de Siqueira JT, Teixeira MJ, de Siqueira SR. High prevalence of orofacial complaints in patients with fibromyalgia: a case-control study. Oral Surg Oral Med Oral Pathol Oral Radiol. 2012 Nov;114(5):e29-34. https://doi.org/10.1016/j. 0000.2012 .04 .001

14. Siqueira JT, Lin HC, Nasri C, Siqueira SR, Teixeira MJ, Heir G, Valle LB. Clinical study of patients with persistent orofacial pain. Arq Neuropsiquiatr. 2004 Dec;62(4):988-96. https://doi.org/10.1590/ s0004-282x2004000600011

15. De Souza Rolim T, Fabri GM, Nitrini R, Anghinah R, Teixeira MJ, de Siqueira JT, Cestari JA, de Siqueira SR. Oral infections and orofacial pain in Alzheimer's disease: a case-control study. J Alzheimers Dis. 2014;38(4):823-9. https://doi.org/10.3233/JAD-131283

16. Melzack R, Terrence C, Fromm G, Amsel R. Trigeminal neuralgia and atypical facial pain: use of the McGill Pain Questionnaire for discrimination and diagnosis. Pain. 1986 Dec;27(3):297-302. https:// doi.org/10.1016/0304-3959(86)90157-0

17. Siqueira SR, Teixeira MJ, de Siqueira JT. Severe psychosocial compromise in idiopathic trigeminal neuralgia: case report. Pain Med. 2010 Mar;11(3):453-5. https://doi.org/10.1111/j.15264637.2010.00813.x

18. Turk DC, Fillingim RB, Ohrbach R, Patel KV. Assessment of psychosocial and functional impact of chronic pain. J Pain. 2016 Sep;17(9 Suppl):T21-49. https://doi.org/10.1016/j.jpain.2016.02.006

19. Ayouni I, Chebbi R, Hela Z, Dhidah M. Comorbidity between fibromyalgia and temporomandibular disorders: a systematic review. Oral Surg Oral Med Oral Pathol Oral Radiol. 2019 Jul;128(1):33-42. https://doi.org/10.1016/j.0000.2019.02.023

20. Koutris M, Visscher CM, Lobbezoo F, Naeije M. Comorbidity negatively influences the outcomes of diagnostic tests for musculoskeletal pain in the orofacial region. Pain 2013 Jun;154(6):927-32. https://doi. org/10.1016/j.pain.2013.03.004

21. Sessle BJ. Editorial: comorbidities associated with orofacial pain and headache: a continuing emphasis. J Oral Facial Pain Headache. 2016 Winter;30(1):5. https://doi.org/10.11607/ofph.2016.1.e 
Appendix 1. The Orofacial Pain Clinic Questionnaire (EDOF-HC).

Date: Phone number:

Name:

Responsible (under 18 yo):

Gender: ; Age: ; Height: ; Weight: ; Ethnicity:

\section{Section 1: Orofacial anamnesis}

1.Pain complaints:

2.Duration:

Description of complaints:

3. Periodicity: () Morning; ( ) Afternoon; ( ) Evening/Night; ( ) Indifferent.

4. How is pain? () provoked; () spontaneous;

5. Pain descriptors: ( ) burning; ( ) throbbing; ( ) pressing; ( ) shock-like; ( ) aching; ( ) stabbing; ( ) other:

6. Intensity: () Mild; ( ) Moderate; ( ) Severe; Numeric verbal scale (0 to 10):

7. Worsening factors:

8. Alleviating factors:

9. Oral habits: () biting tongue; ( ) biting oral mucosa; ( ) biting lips; ( ) other:

10. Chewing: () Right; () Left; ( ) Bilateral.

11. Chewing quality: ( ) good; ( ) regular; ( ) bad; ( ) doesn't know; ( ) painful; ( ) other:

12. Sensation of tired face: () no; () yes: () when waking-up; () when chewing; ( ) when talking; () when smiling;

() other:

13. Teeth clenching or grinding: ( ) sleep bruxism; ( ) awake bruxism; ( ) doesn`t know;

() who told you?

14. Articular noises: ( ) no; ( ) yes: side:

() chewing; () other:

15. Pain in mandibular movements: ( ) no; ( ) yes: ( ) mouth opening; ( ) protrusion; ( ) right laterality; ( ) left laterality; () other:

16. Earache: () no; () yes: side:

17. Headache: ( ) no; ()y es: where:

Did you go to ENT evaluation? ( ) no; ( ) yes:

18. Body pain: ( ) no; ( ) yes: where:-______________._. Did you go to the physician? ( ) no;
19. Have you ever undergone surgery, or were you involved in an accident? ( ) no; ( ) yes. Did you go to the neurologist? () no; () yes:

Describe it:

20. Point to the areas of your facial pain:

21. Point to the areas of your body pain:

() right; () left; () bilateral. () right; () left; ( ) bilateral.
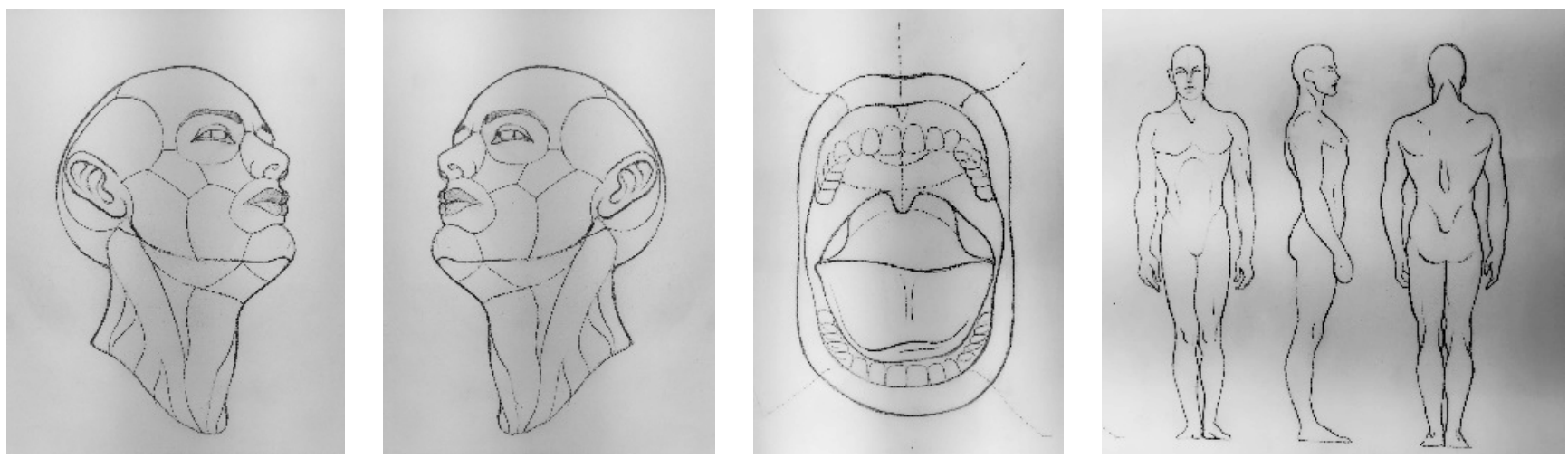

\section{Section 2: medical anamnesis}

1.Medical history:

() rheumatoid arthritis; () asthma; () bronchitis; () hepatites; () amygdalitis; () stroke; () fibromyalgia; () sinusites; () rhinitis; () hypertension; ( ) diabetes; () gastric ulcer; ( ) gastritis; ( ) heat disease; () kidney disease; ( ) depression; ( ) infection; ( ) migraine; () herpes zoster; ( ) Paskinson's Disease; ( ) Other:

2.Are you currently in medical treatment: () no; () yes.

Describe:

\section{Medications in use:}

\section{Section 3: clinical examination}

1. Face: ( ) assymetry; ( ) prognatism; ( ) laterognatism; () Hypertrophy: ( ) masseter / ( ) temporal; ( ) right / () left.

2. Facial skin:

3.Linfonodes:

4. Oral mucosa:

5. Tongue:

6. Neurological abnormalities:

7. Periodontal tissues:

8.Teeth (decay, missing, percussion/sensivity tests): 
9. Occlusal interferences:

10. Open bite: ( ) no; ( ) yes.

11. Crossbite: () no; () yes: () anterior / () posterior - () right / () left.

12. Deep bite: () no; ( ) yes: ( ) a / () b / () c.

13. Teeth abrasion: () no; ( ) yes: ( ) incisal; ( ) incisal third; () middle third; ( ) cervical third.

14. Angle classification: () I; () II; () III.

15. Mandibular movements: maximum mouth opening:______mm - () no pain / ( ) painful. Protrusion:

() right laterality:______mm - () no pain / ()painful. Left laterality: mm - () no pain / () painful.

mm - () no pain / () painful.

16. Temporomandibular joint noises: () no; () POP; ()mild crepitation; ()severe crepitation;

() Click. () Right / () Left. () start mouth opening / () middle mouth opening / ( ) end mouth opening / () start mouth closing /

() middle mouth closing / ( ) end mouth closing.

17. Temporomandibular joint (TMJ) and muscular palpation:

\begin{tabular}{|l|l|l|l|}
\hline & Right & Left & \\
\hline TMJ - lateral & & & \\
\hline TMJ - posterior & & & \\
\hline Masseter inferior & & & \\
\hline Masseter middle & & & \\
\hline Masseter superior & & & \\
\hline Masseter intraoral & & & \\
\hline Temporal anterior & & & \\
\hline Temporal middle & & & \\
\hline Temporal posterior & & & \\
\hline Temporal intraoral & & & \\
\hline Digastric anterior & & & \\
\hline Digastric posterior & & & \\
\hline Esternocleidomastoid superior & & & \\
\hline Esternocleidomastoid middle & & & \\
\hline Esternocleidomastoid inferior & & & \\
\hline Splenius cervical & & & \\
\hline Splenius head & & & \\
\hline Suboccipital & & & \\
\hline Trapezius shoulder & & & \\
\hline Trapezius neck & & & \\
\hline
\end{tabular}

18. Observations:

19. Diagnostic hypotheses:

20.Complementary exams

20. Final hypotheses:

21. Treatment: 